\title{
EM BUSCA DE UM CONCEITO DE ASSÉDIO MORAL: REVISITANDO A NECESSIDADE DO DANO PSÍQUICO PARA SUA CONFIGURAÇÃO
}

Renato de Almeida Oliveira Muçouçah

Mestre e Doutor em Direito do Trabalho pela Faculdade de Direito da Universidade de São Paulo (USP). Professor do curso de Mestrado em Direito da Universidade Federal do Maranhão (UFMA). Professor dos cursos de Graduação e Mestrado em Direito da Universidade Federal de Uberlândia (UFU), Minas Gerais. 0 autor registra seu agradecimento pelo apoio financeiro concedido pela Fundação de Amparo à Pesquisa do Estado de Minas Gerais (FAPEMIG), que viabilizou a apresentação da presente pesquisa acadêmica.

\section{Resumo}

O presente trabalho tem como escopo estudar o fenômeno assédio moral e buscar situá-lo para além das fronteiras da perseguição ou dano psicológico, como se verifica até mesmo em julgados bastante recentes. Partindo de uma breve introduçáo histórica acerca dos fundamentos exigidos para reconhecer uma relação de emprego como válida, e também buscando compreender relaçôes em que não há formalização, nota-se que o poder diretivo do empregador e a forma de sua manifestaçáo podem constituir-se em elementos facilitadores da prática de assédio moral. Ato seguinte busca-se propor um conceito amplo de assédio moral, não baseado apenas no dano psíquico, de maneira a abarcar diversas formas de violência existentes em relaçôes de emprego, no afă de conferir-lhes formas para tutela jurídica que reprima ou previna tais práticas. O poder diretivo do empregador acabou transformando-se em força e pressão produtivas na cultura de empresas, o que poderá consubstanciar-se em assédio moral, independentemente de existirem ou não danos de qualquer natureza. Faz-se necessária, portanto, uma releitura do conceito de assédio moral, a fim de que se possa tutelar com mais presteza relaçóes tidas como "normais" em ambientes do trabalho, mas que, em verdade, constituem atos violentos de desrespeito a direitos fundamentais do trabalhador.

\section{Palavras-chave}

Assédio moral; Poder diretivo do empregador; Dano psicológico; Cultura da empresa. 


\section{Abstract}

This research aims study the mobbing phenomenon and seek to place it beyond the borders of persecution or psychological damage, as can be observed on very recent court decisions. After a brief historical introduction about the fundamentals required to recognize an employment relationship as valid, and also trying to understand relationships where there is not formal characterization, the directive power of the employer and the form of its manifestation can be constituted in facilitating elements to practice of mobbing. The next act seeks to propose a broad definition of mobbing, not just based on psychic damage, in order to cover various forms of violence in employment relationships, with the desire to give them ways to legal protection to suppress or prevent such practices. The directive power of the employer eventually can become the productive force and the pressure in the culture of companies, which may constitute the mobbing, although whether or not damages of any kind. It is necessary, therefore, a reinterpretation of the concept of mobbing, which defends them with more promptness relations considered "normal" in the workplace, but which, in fact, are violent acts of disrespect about fundamental rights of the worker.

\section{Key words}

Mobbing; Employer's directive power; Psychic damage; Company practices.

\section{1. À Guisa de Introdução}

Segundo Robert Castel ${ }^{1}$, no curso de existência do modo de produção capitalista os trabalhadores vivenciaram algumas formas de integração, dentre elas a condição proletária e a condição operária. Hoje, vive-se na sociedade salarial: praticamente todos os seres humanos vivem de algum tipo de remuneração, seja oriunda do trabalho subordinado, do autônomo ou de novas formas de conquista de dinheiro por meio do labor humano. $\mathrm{Na}$ primeira fase da integração, havia quase que a exclusão dos proletários do corpo social: sujeitos de direitos, considerados formalmente iguais aos seus contratantes, suas questóes - como a própria nomenclatura escolhida sugere - resolviam-se com base no contrato, no acordo de vontades individualmente considerado.

Nesse diapasão, o proletário não existe para a sociedade porque apenas produz para ela; é, no entanto, tão miserável que não consegue sequer consumir o que produz. Sem qualquer força política ou construção de identidade com aqueles que vivem em condições

1 CASTEL, Robert. As metamorfoses da questáo social: uma crônica do salário. Trad. Iraci D. Poleti. 6. ed. Petrópolis: Vozes, 1998. p. 415-436. 
semelhantes às suas, o homem, nesta fase, trabalha apenas para reproduzir-se materialmente. A posterior passagem à condição operária traduziu-se na integração por outra maneira: a percepção da lógica subordinante, que afinal foi a alavanca do mundo do trabalho no fito de constituir uma espécie de coesão social ${ }^{2}$, com a qual se forjou uma identidade de classe. Aliás, é nesta fase que surge o direito do trabalho e o salário deixa de ser a mera retribuição pontual pelas tarefas desempenhadas, nos dizeres de $\mathrm{Castel}^{3}$. Ele passa a ser mais: garante direitos, permite o acesso a direitos sociais como aposentadoria, auxílio por enfermidade relacionada ou não ao trabalho, assim como possibilita à classe trabalhadora conquistar o consumo, a instrução, o lazer e a propriedade.

A assertiva pode ser corroborada pelos estudos de François Ewald acerca do chamado Estado-Providência: a sociedade industrial trouxe um problema que desafia até mesmo os postulados liberais, qual seja, os acidentes do trabalho ${ }^{4}$. Conforme o autor, o direito em si não contém uma "essência": trata-se de uma categoria de pensamento que descreve certas práticas, como práticas normativas, racionais mas, sem dúvidas, também práticas de coerção e sanção social ${ }^{5}$. E como poderia haver a reparação dos acidentes do trabalho sem a responsabilização de alguém - responsabilidade esta que se baseava nos princípios liberais da eventual culpabilidade do empregador? Sem dúvidas, a solução encontrada foi a socialização de riscos, promovida pelo Estado por meio de algum Instituto financiado pelos cofres públicos e pelos particulares que desenvolvessem atividades perigosas.

O direito buscou ampliar o conceito de trabalhador para fins de proteção social aos infortúnios, vez que - nas palavras do já citado Castel - vive-se na sociedade salarial. Esta expansão do conceito de trabalhador, contudo, serviu à inclusão social e à proteçáo de pessoas pelo Direito da Seguridade Social, mas náo gerou reflexos para o Direito do Trabalho ${ }^{6}$. Este continuou preso aos clássicos institutos do reconhecimento de relação de emprego (e consequente conquista de direitos sociais constitucionalmente assegurados): quando houver trabalho subordinado, com pessoalidade, realizado de maneira não eventual, de forma onerosa e prestado por pessoa física, haverá direitos sociais elementares, ínsitos ao Direito do Trabalho, a serem aplicados. Ausente algum ou alguns desses elementos, inexistirá relação de emprego a ser reconhecida e, portanto, direitos sociais a serem garantidos a quem vive de seu trabalho.

Por certo não se está a falar, aqui, do surgimento do Direito do Trabalho, cujas lutas remontam aos primórdios da Revolução Industrial e a algumas leis esparsas do século

2 ROMAGNOLI, Umberto. La libertad sindical, hoy. Revista de Derecho Social, v.4, n. 14, p. 9-23, abr./jun. 2001. p. 20.

3 Op. cit., p. 416

4 EWALD, François. L'Etat Providence. Paris: Bernard Grasset, 1986. p. 85-90.

5 Id. p. 30.

6 CAMERLYNK, G. H. Traité de droit du travail: contrat de travail. Paris: Dalloz, 1968. p. 54. 
XIX, existentes em vários países. Todavia, é na codificação deste ramo especializado do direito que a Itália muito influenciou o Brasil. Quem o afirma é Evaristo de Moraes Filho: "vivemos até 1945 num regime corporativo-fascista, nos moldes do italiano, cujo ordenamento jurídico copiamos servilmente. Importamos por isso mesmo muitos de seus conceitos doutrinários acêrca de nossa ciência"7. Todavia, consoante raciocínio do mesmo autor, com a redemocratização dos países no pós-guerra, a inspiração fascista na leitura do direito laboral findou-se tanto no Brasil quanto na Itália, repudiando o corporativismo sindical (traço maior do regime citado) ${ }^{8}$.

O tratadista italiano Lodovico Barassi, em obra de 1949, inicia seu texto firmando a fisionomia do direito do trabalho na relaçáo entre o empregador e seu subordinado, a qual chama de relação de trabalho ${ }^{9}$. Não restam mais, pois, influências do corporativismo fascista - ao menos não ostensivamente. De qualquer forma, para além das discussóes de seu tempo (o contratualismo ou acontratualismo existente na relação empregatícia, tema também amplamente debatido no Brasi ${ }^{10}$ ), Barassi fixa os requisitos necessários para o reconhecimento de um contrato de emprego: um trabalho prestado por pessoa física ${ }^{11}$, com inserção em um empreendimento, sendo o empregado sempre estranho ao risco empresarial (alteridade), de maneira a prestar seu trabalho ao empregador de maneira subordinada e onerosa ${ }^{12}$. Estes foram (e são), desde os primeiros tempos da legislação trabalhista brasileira e italiana, os principais requisitos para o reconhecimento da existência de um contrato de emprego.

Com o passar do tempo, tanto Itália quanto Brasil - até mesmo pela similaridade de seus ordenamentos jurídicos trabalhistas - desenvolveram suas teses e enfrentaram questóes similares. Já em obra de 1984, Renato Scognamiglio compreende como requisito

7 MORAES FILHO, Evaristo de. Introduçáo ao Direito do Trabalho. Rio de Janeiro: Forense, 1956. v. 1, p. 263.

8 Id., p. 267-269.

9 BARASSI, Lodovico. Il diritto del lavoro: le fonti, il rapporto di lavoro, le qualifiche. Milano: Giuffrè, 1949. v. 1, p. 5.

10 Vide MESQUITA, Luiz José de. Direito disciplinar do trabalho. São Paulo: Saraiva, 1950, p. 20-41, autor brasileiro defensor do acontratualismo da relação de emprego (a chamada visão institucional). Como bem explanado pelo citado autor, a empresa envolve a ideia de uma "obra comunitária", em que é necessário o elemento da comunhão entre os participantes (quais sejam, empregador e empregados) para que a finalidade social seja atingida. O poder nesta empresa é detido pelo proprietário, afinal, é ele quem une o capital ao trabalho, mas tal poder visa atender aos interesses da empresa, e não ao seu próprio. O empregado, assim, é um colaborador na empresa, que labora com vistas à consecução da finalidade empresarial, sendo corresponsável pelo sucesso ou fracasso do capital. Lodovico Barassi, Op. cit., p. 224-241, tenta conciliar a teoria institucional e a contratualista, dizendo ser "contratual" a "inserção do trabalhador na empresa" e sua colaboração para com o empregador. A discussão permeou as décadas de 1930 a 1950, até firmar-se, em coro uníssono, a natureza puramente contratual da assim chamada "relação" de emprego.

11 BARASSI, Lodovico, Op. cit., p. 191.

12 Id. p. 242-257. 
necessário para a formação válida do contrato de emprego a pessoalidade do trabalhador, assim como a habitualidade nos serviços, ideia ínsita à subordinação ${ }^{13}$.

Apenas para fim de ilustração, aproximadamente na mesma época em que Renato Scognamiglio publicava seu livro na Itália (cuja primeira edição é de 1969), no Brasil Mozart Victor Russomano sustentava idênticos requisitos para o reconhecimento da existência ou validade de um contrato de emprego ${ }^{14}$. Estes requisitos permanecem como aqueles exigidos até a atualidade para a caracterização da relação de emprego, como se pode notar - também exemplificativamente - pela obra de Maurício Godinho Delgado ${ }^{15}$.

Everaldo Gaspar Lopes de Andrade advoga que, em face das diversas fases capitalistas já vivenciadas no globo (incluindo a atual, que é a do capitalismo global e financeiro em sua fase pós-industrial), o objeto central do direito do trabalho não pode mais ser considerado como o trabalho subordinado: o trabalho informal se encontra "completamente distanciado dos sistemas de proteção instituídos pelo Direito do Trabalho" ${ }^{16}$. Vive-se o tempo, pois, dos trabalhos existentes à margem da aplicação do direito ou, numa expressão, dos trabalhos marginalizados.

Considera-se, porém, que a prática de assédio moral acaba por ser potencializada em relaçóes informais, irregulares ou marginalizadas, pois apesar da irregularidade - ou até ilicitude, em muitos casos, da atividade - trabalhadores e detentor do capital se encontrarão em zonas atípicas nas quais se torna difícil ou mesmo impossível o reconhecimento de um contrato de emprego, em que pese a existência da subordinação, máxime no contínuo recebimento de ordens e constante submissão dos obreiros aos ditames do dador de ordens.

\section{A Subordinação e o Poder Diretivo do Empregador como Elementos Propi- ciadores do Assédio Moral}

A lógica do conceito de trabalho contratualmente subordinado, pelo qual se transfere ao empregador o poder de dirigir a execução de serviços, fiscalizá-la e mesmo punir seus empregados auxiliou, em imensa medida, a prática de assédio moral. Nas relaçóes de trabalho irregulares, clandestinas ou mesmo ilegais (terceirização, falso estágio acadêmico, trabalho do cabo eleitoral, a prostituição, o homem-seta, a diarista, a cuidadora,

13 SCOGNAMIGLIO, Renato. Diritto del Lavoro. 2. ed. Bari: Cacucci, 1984. p. 107-109; p. 149-162.

14 RUSSOMANO, Mozart Victor. Curso de Direito do Trabalho. Rio de Janeiro: José Konfino, 1972. p. 78-108.

15 DELGADO, Maurício Godinho. Curso de Direito do Trabalho 13. ed. São Paulo: LTr, 2014. p. 289308.

16 ANDRADE, Everaldo Gaspar Lopes de. Direito do Trabalho e Pós-Modernidade: fundamentos para uma teoria geral. São Paulo: LTr, 2005. p. 77. 
os apontadores do jogo do bicho, a manicure, o motoboy, o trabalho em presídios, etc. ${ }^{17}$ potencializam um sem-número de situações nas quais, inexistindo qualquer tutela laboral, o assédio moral poderá dar-se de maneira ainda mais acentuada, em razão do poder conferido ao dador de ordem (ou empregador suposto) para ditar o processo de execuçáo do trabalho, ainda que à margem da lei. Poder, de forma genérica, é a possibilidade de alguém impor uma conduta ou um conteúdo a outrem, e está presente em quase todas as relaçóes na sociedade.

Conforme a escorreita análise de Gérard Lebrun, ao conceito de poder está ligada a ideia de força. Um exemplo não pode ser mais claro: se um partido tem peso político, é porque tem força para mobilizar um determinado número de eleitores; se um sindicato também possui peso político, é pelo fato de ter ele poder para deflagrar uma greve. Força não é necessariamente a posse de meios violentos de coerção, mas de meios que permitam a um determinado agente influir na conduta de outro. Em outras palavras, "a força é a canalização da potência", entendendo a potência como "toda oportunidade de impor a sua própria vontade, no interior de uma relação social, até mesmo contra resistências, pouco importando em que repouse tal oportunidade"18.

Reinhard Bendix demonstra como, historicamente, a disciplina e a autoridade se fizeram presentes nas relaçóes de trabalho, exatamente como forma de incentivar comportamentos.

O autor cita a obra de Robert Owen, que se fez presente numa época em que os empregados eram tratados como quaisquer dos outros fatores da produçáo. $\mathrm{O}$ método owenista, contudo, concebia a relação de emprego como algo "amo-servidor", na qual o amo pensava por seu servidor e o protegia contra infortúnios da vida, contra suas próprias debilidades, criando-se entre eles uma relação verdadeiramente amistosa. Mais até que amistosa: relaçóes morais, sentimentais, mas ao mesmo tempo autoritárias, já que o amo (empregador) exercia sua vontade arbitrariamente sobre os servos (empregados), vez que detinha a legitimidade consentida por estes para saber, em nome de todos eles, o que seria bom ou ruim para a empresa e para o destino individual de cada operário ${ }^{19}$.

Esse tipo de concepção, porém, foi superada pela produção industrial em grande escala que pressupunha, por sua larga dimensão, um modo diretivo mais impessoal. Por seu turno, a classe empresária passou a enfatizar a ideologia do esforço individual, que se

17 Para uma análise mais detida acerca desses diversos tipos de trabalho, consultar SOUTO MAIOR, Jorge Luiz; GNATA, Noa Piatã Bassfeld (orgs.). Trabalhos marginais. São Paulo: LTr, 2013.

18 LEBRUN, Gérard. O que é poder. 14. ed. São Paulo: Brasiliense, 1996. p. 12.

19 BENDIX, Reinhard. Trabajo y autoridad en la industria: las ideologías de la dirección en el curso de la industrialización. Trad. Ítalo A. Manzi e Ricardo Malfé. Buenos Aires: Editorial Universitaria de Buenos Aires, 1966. p. 51-53. 
lograr êxito, traz ao trabalhador uma recompensa; esta ideologia (trinômio esforço, êxito e recompensa) foi amplamente utilizada no movimento patronal antissindical, por afirmar ao trabalhador que este somente poderia modificar suas condiçóes de vida se ganhasse a confiança e o respeito de seu empregador, e não por possíveis confrontos ${ }^{20}$. Trata-se da lógica da concórdia em substituição ao embate.

No entanto, a indústria moderna náo poderia mais ser pessoalmente controlada pelo empregador. Desta feita, não se poderia confiar mais na relação "amo-servo"; a produção de linha, para obter êxito, concentrou-se em castigar severamente os obreiros se estes faltavam para com a produção. Este tipo de direção pressupunha a onipresença do medo e da coerção para que os empregados trabalhassem com vistas à máxima produção. $\mathrm{O}$ discurso ideológico, entretanto, foi mantido apenas para acentuar o dever da submissão ${ }^{21}$.

Nesse sentido, observamos que o poder exercido pelo empregador sobre o empregado não se limita à dominação em sua forma mais primária. Este poder é também autoridade, pois existe ao "seu lado a força do hábito; náo precisa justificar-se a todo instante, nem provar, incessantemente, que oposição alguma é suficientemente forte para derrubá-lo"22.

Encontra-se legitimado, em verdade, pelos discursos jurídicos. Segundo Michel Foucault há "relaçóes de poder múltiplas que atravessam, caracterizam e constituem o corpo social" e estas não se dissociam, se estabelecem e nem mesmo funcionam "sem uma produção, uma acumulação, uma circulação e um funcionamento do discurso" ${ }^{23}$. Esse mesmo discurso que confere veracidade à fala jurídica do poder diretivo do empregador é um dos vários poderes dispersos pela sociedade, e que representam, para a burguesia, a consecução de um determinado interesse.

Os discursos jurídicos acerca da legitimidade do poder diretivo do empregador em nosso ordenamento jurídico se legitimam apenas pela doutrina e pela jurisprudência, posto que baseados na interpretaçáo tendenciosa do lacônico caput do artigo $2^{\circ}$ da Consolidação das Leis do Trabalho, aliada à exegese de algumas outras normas esparsas e previstas para casos estritamente pontuais, não generalizantes, do curso da relação jurídica de emprego, como os artigos 468, 469, 474 e 482 (este que pouco se relaciona com o construído tema do poder diretivo do empregador, mas sim, e em verdade táo-só, com a resolução negocial trabalhista), todos também do texto consolidado.

20 Id., p. 286.

21 Id., p. 211-214.

22 RUSSELL, Bertrand. O poder: uma nova análise social. Trad. Brenno Silveira. São Paulo: Companhia Editora Nacional, 1957. p. 26-27.

23 FOUCAUlT, Michel. Microfísica do Poder. Trad. Roberto Machado. 21. ed. Rio de Janeiro: Graal, 2005. p. 179. 
O discurso jurídico mais tradicional demonstra esse poder exercido sobre os empregados como uma inelutável necessidade técnica. E se pode observar, em conformidade com as citaçóes de Russel e de Foucault, que o discurso dos juristas vai muito além: este discurso legitima o poder, operacionalizando-o; é força inelutável, passível de cumprimento sem qualquer análise de conteúdo pelo sujeito passivo a ele sujeitado. E tudo isso é formado pelo "poder da opinião", que se dissemina nos discursos jurídicos e, muito mais que neles, na prática cotidiana empresarial exercida pelo poder diretivo do empregador.

O discurso somente existe e é eficiente porque há indivíduos que, entre si, concebem homogeneamente uma linguagem em que se comunicam e, pela inteligência, apreendem o símbolo traduzido por essa linguagem. Os símbolos, assim, tornam possível o consenso "do sentido do mundo social que contribui fundamentalmente para a reprodução da ordem social: a integração <<lógica >> é a condição da integração <<moral>>"24. O símbolo possui este papel estruturante na transmissão de valores mas, ao mesmo tempo, ele é um estruturante que pode ser estruturado a serviço de disseminar valores de um interesse particular, a saber, do empregador, e não dos interesses coletivos (ainda que da "empresa").

Segundo Pierre Bourdieu,

não basta notar que as relaçôes de comunicação são, de modo inseparável, sempre, relaçóes de poder que dependem, na forma e no conteúdo, do poder material ou simbólico acumulado pelos agentes (ou pelas instituiçôes) envolvidos nessas relaçóes e que, como o dom ou o potlatch, podem permitir acumular poder simbólico. É enquanto instrumentos estruturados e estruturantes de comunicação e de conhecimento que os <<sistemas simbólicos>> cumprem a sua função política de instrumentos de imposição ou de legitimação da dominação, que contribuem para assegurar a dominação de uma classe sobre outra (violência simbólica) dando o reforço de sua própria força às relaçóes de força que as fundamentam e contribuindo assim, segundo a expressão de Weber, para a $<$ domesticação dos dominados $>^{25}$.

O poder simbólico do discurso acerca da legitimidade das diretivas do empregador, que se transforma mais tardiamente em discurso de autoridade, em discurso defensor da autoridade patronal, objetiva a persuasão de um determinado grupo com o objetivo de convertê-lo; ato seguinte, os sujeitos "convertidos" expóem a opinião de forma convincente ao resto da comunidade, de forma constante e, por fim, a grande maioria resta plenamente crente da legitimidade da ordem ou do costume instituídos, o que torna

24 BOURDIEU, Pierre. O Poder Simbólico. Trad. Fernando Tomaz. 8.ed. Rio de Janeiro: Bertrand Brasil, 2005. p. 10

25 Id., p. 11. 
desnecessário, em absoluto, o uso da força física ${ }^{26}$. Para Friedrich Engels, autoridade pressupóe subordinação; no entanto, para ele, a autoridade é imprescindível à organização produtiva. A questão a ser levantada corresponde a quem é o sujeito detentor do poder de organização, se o empregador ou os trabalhadores. No capitalismo seria o primeiro, e no socialismo os proletários - mas, de qualquer forma, haveria uma decisão de autoridade a ser respeitada, com vistas à consecução do trabalho parcelar. Portanto, para Engels a autoridade não desaparece; ela apenas se transforma. Se não houvesse a coordenação das atividades, e uma se sujeitando de certa maneira à outra, enfim, ter-se-ia o caos. Logo, para este, o poder do capital sobre o trabalho é apenas econômico ${ }^{27}$.

O conceito de Engels fica claro quando examinamos o modelo de produção implementado na União das Repúblicas Socialistas Soviéticas, dotado de uma hierarquia bastante complexa, em cujo vértice encontrava-se a "comissão soviética de controle", nomeada pelo Partido Comunista. E mesmo em termos da análise de quem está no comando, ou de quem exerce a autoridade sobre outros indivíduos, a tendência demonstrada pelo modo autoritário de produção capitalista ou socialista soviético pouco conseguem diferenciar-se, porque teoria e ação tornam-se assuntos doutrinários inseparáveis e, na prática, tanto em um sistema quanto em outro, a produtividade sempre maior continua a ser a prova do sucesso da direção empresarial ${ }^{28}$. Por isso, Reginaldo Melhado oferece um escorreito ponto de vista:

o trabalho coletivo requer, inelutavelmente, coordenação técnica, mas o poder na relação entre capital e trabalho, tal como o conhecemos em sua forma atual, é originário da separação entre o trabalho intelectual e trabalho manual e é produto do capitalismo. Advém de fatores diversos, alguns intrínsecos à própria relação individual de trabalho e outros que podemos denominar "heteronômicos". Não resulta da produção, e sim do modo de produção capitalista ${ }^{29}$.

A posição de Engels poderia levar à conclusão de que a disciplina das máquinas possui lógica própria, neutra, independentemente do sujeito titular dos meios de produção. Em suma: a autoridade dentro da empresa vista como apenas uma necessidade técnica desvinculada de seu valor político, que simplesmente existe, independentemente do fato

26 RUSSELL, Bertrand. O poder: uma nova análise social. Trad. Brenno Silveira. São Paulo: Companhia Editora Nacional, 1957. p. 110.

27 ENGELS, Friedrich. Sobre a autoridade. in: MARX, Karl; ENGELS, Friedrich. Obras Escolhidas. v. 2. São Paulo: Alfa-Ômega, s/d. p. 185-187.

28 BENDIX, Reinhard. Trabajo y autoridad en la industria: las ideologías de la dirección en el curso de la industrialización. Trad. Ítalo A. Manzi e Ricardo Malfé. Buenos Aires: Editorial Universitaria de Buenos Aires, 1966. p. 376-377.

29 MELHADO, Reginaldo. Poder e Sujeiçáo: os fundamentos da relação de poder entre capital e trabalho e o conceito de subordinação. São Paulo: LTr, 2003. p. 17. 
de nela coabitar uma relação de forças. O poder e a autoridade dentro da empresa (que se poderia resumir no chamado poder diretivo) cumprem, a par da necessidade técnica, a função de eliminar os interesses antagônicos existentes entre empregados e empregadores, os quais se plasmam na relação de emprego, na esteira do que sustenta o autor acima citado.

A prova mais elementar do sustentado no parágrafo anterior radica-se exatamente no conteúdo normativo das diretivas do empregador. Se o poder diretivo do empregador tivesse unicamente a função de organização da atividade produtiva, haveria coordenação, e não subordinação. Aliás, historicamente pode-se perceber a dupla função desta espécie de poder.

Dentro de um espaço de trabalho haver quem manda e quem é mandado é algo que foi concebido historicamente. Haverá revolta se as ordens são inflexíveis, ou contentamento se não o forem tanto, mas a dominação em si mesma é tida como legítima. E mais: empregados e empregadores são postos em mesmo patamar, como que sendo, ambos, "vítimas" da regra - a única vontade superior, que foi firmada já, anteriormente, no contrato de trabalho. Portanto o poder diretivo cumpre, além da necessidade técnica de operacionalização do trabalho, a função de eliminar antagonismos de classes em favor da classe economicamente mais forte, e é por isto que este poder ganha, na forma hodierna das relaçóes de trabalho, o conteúdo normativo na forma de vigilância, coerção, direção, enfim, de poder privado.

Octávio Bueno Magano foi considerado, no Brasil, um dos autores de referência na questão do estudo do poder diretivo do empregador. Para ele, no plano da relação jurídica intersubjetiva entre empregado e empregador, o poder diretivo surge como direito potestativo, porque atribui ao empregador "a capacidade de influir a qualquer momento sobre a relação jurídica existente, determinando o conteúdo das prestaçóes das partes" 30 , tendo em vista que o detentor do direito potestativo - o empregador - não necessita da colaboração do sujeito passivo da relação obrigacional (empregado) para que o conteúdo ordenado seja cumprido. Nesse aspecto, a obra de Magano diferencia-se em absoluto dos conceitos de Alfredo Montoya Melgar, que parece fundamentar o poder diretivo do empregador em duas situaçóes distintas: uma, que é originária da sua condiçáo de credor de trabalho, obtida por meio do negócio jurídico trabalhista; outra, fundamentada na propriedade privada mesmo, posto ser o empregador um empresário, ou seja, aquele que detém a titularidade da empresa ${ }^{31}$. Tal visão, embora menos erudita que a de Magano, parece refletir melhor a realidade por desprendê-la de um conceito que, em verdade, é dogma: a necessidade inelutável da existência da subordinação.

30 MAGAnO, Octavio Bueno. Do Poder Diretivo na Empresa. São Paulo: Saraiva, 1982. p. 59.

31 MONTOYA MELGAR, Alfredo. El poder de dirección del empresário. Madrid: Instituto de Estudios Políticos, 1965. p. 37. 
Num caminho que se pode denominar neoinstitucionalista, Octávio Bueno Magano atribui ao chamado poder diretivo o conceito de direito-função: "o poder atribuído ao sujeito de direito para a tutela não do seu próprio interesse, mas de um interesse alheio, quase sempre superior" 32 . Assim, ocorreria certo divórcio entre os interesses do empresário e os da empresa, haja vista a função social que ela tem. Magano chega a comparar o poder diretivo ao poder familiar, dizendo que o poder familiar (pátrio poder) antigo realizava apenas o interesse individual do homem, chefe de família; modernamente, ele é gerido em prol da família, do grupo.

Essa sensível mudança teria ocorrido também, no curso da História, com o poder diretivo do empregador, mais voltado à satisfação dos interesses da empresa que do empresário individualmente considerado. Quanto mais ela sofrer a incidência do interesse coletivo e dos trabalhadores em sua existência, menos a empresa terá a materialização do interesse subjetivo do empresário, concretizando-se as decisóes tomadas em seu bojo como "codecisóes", ou ainda, como "decisóes da própria empresa" ${ }^{33}$. Desta forma, define: "poder diretivo do empresário é a capacidade, oriunda do seu direito subjetivo, ou então da organização empresarial, para determinar a estrutura técnica e econômica da empresa”, com o claro objetivo de "dar conteúdo concreto à atividade do trabalhador, visando às finalidades daquela" 34 .

Entretanto, criticando a posição adotada por Octávio Magano, Reginaldo Melhado leciona sobre a teoria do direito-função:

sua fragilidade reside na abstraçáo do empreendimento capitalista como algo definido comunitariamente; como se a empresa tivesse seu nascedouro e sua continuidade pendente de uma "idéia comum" da qual também tomassem parte os trabalhadores. Estes, bem ao contrário, passam a integrar a "comunidade de trabalho" depois de fixados sua finalidade industrial, mercantil ou de serviços e seu projeto de realização. Fazem-no por razóes muito próprias, que refogem claramente aos marcos dos interesses do capitalista: não buscam nada mais que as condiçóes materiais de sua reprodução. Seu interesse é apenas o salário, e é oposto ao interesse do empresário, pois nutre a expectativa da maior valorização possível da força de trabalho. E a valorizaçáo do trabalho reduz a taxa de mais-valia e inibe o auto-incremento do capital, por seu turno, só é capital por perseguir este incremento. A relação é antagônica ${ }^{35}$.

32 Op. cit., p. 64.

33 MAGANO, Octavio Bueno. Do Poder Diretivo na Empresa. Sáo Paulo: Saraiva, 1982. p. 65-68.

34 Id., p. 94.

35 MELHADO, Reginaldo. Poder e Sujeiçáo: os fundamentos da relação de poder entre capital e trabalho e o conceito de subordinação. São Paulo: LTr, 2003. p. 84. 
A incongruência apontada na obra de Magano é por ele mesmo tornada palpável, quando salienta que o poder diretivo, mesmo concebido como direito-função, será sempre uma prerrogativa do empresário ${ }^{36}$, e não necessariamente comunitária. Ou seja, ainda que cumpra a empresa sua função social com a coletividade e os trabalhadores, em última análise, o poder diretivo do empregador é força que, além de administrar as atividades produtivas do trabalho, oblitera os antagonismos de classe, utilizando-se para tal fim dos meios que dão conteúdo à organização da administração empresarial: dirigi-la, regulamentá-la, fiscalizá-la e punir os trabalhadores que descumprirem tais diretivas. Essa é a definição de poder diretivo do empregador tomada como escorreita, salientando-se que esse não possui qualquer fundamentação legal ou institucional, a não ser aquela firmada pela vontade (viciada) do empregado no negócio jurídico firmado com seu empregador, consubstanciado no contrato de trabalho.

Por óbvio, as prerrogativas conferidas ao empregador facilitam o exercício abusivo do direito, de maneira tal a poder configurar-se situaçóes que, reiteradamente praticadas, ensejarão o que se denomina assédio moral. Nos trabalhos irregulares, clandestinos ou ilícitos - até mesmo pela ausência de tutela legal - a situação poderá agravar-se. Um bom exemplo é o funcionalismo público: em virtude da estabilidade conferida aos servidores públicos não raro estes serão "punidos" por outra via, que poderá ou não configurar prática de assédio moral. Essa violência na execução de atividades laborais constitui uma das faces mais antigas das relaçóes de trabalho. $\mathrm{O}$ assédio moral em tais relaçóes é apenas espécie da violência cotidiana a que são submetidos muitos dos trabalhadores de todo o mundo. Não existe em nosso ordenamento jurídico qualquer previsão específica que esquadrinhe os contornos de tal conceito, e a doutrina e a jurisprudência ainda são claudicantes neste sentido. O tema, também conhecido como psicoterrorismo, tornou-se amplamente divulgado pelas palavras de Marie-France Hirigoyen:

[...] o assédio moral no trabalho é definido como qualquer conduta abusiva (gesto, palavra, comportamento, atitude...) que atente, por sua repetição ou sistematização, contra a dignidade ou integridade psíquica ou física de uma pessoa, ameaçando seu emprego ou degradando o clima de trabalho ${ }^{37}$.

O sujeito ativo (assediador) em regra é o empregador ou superior hierárquico que lhe faça as vezes, mas poderá ser também o próprio subordinado; o sujeito passivo desta prática (assediado) geralmente é o empregado, mas também poderá existir casos em que poderá ser o superior hierárquico. A fim de caracterizar a prática do assédio moral é preciso

36 MAGANO, Octavio Bueno. Do Poder Diretivo na Empresa. São Paulo: Saraiva, 1982. p. 65.

37 HIRIGOYEN, Marie-France. Mal-estar no trabalho: redefinindo o Assédio Moral. Trad. Rejane Janowitzer. 2.ed. Rio de Janeiro: Bertrand Brasil, 2005. p. 17. 
conduta, comportamento ou atos atentatórios a direitos fundamentais da personalidade humana, reiteração e sistematização do feito, bem como a consciência de assediar do agente, ou, ao menos, ser "previsível seu efeito danoso sobre o ambiente de trabalho e sobre a integridade psicofísica da vítima" ${ }^{38}$. Esta vertente "psicologizante" do assédio moral - que exige a ocorrência de dano psíquico, ou ataque à integridade física ou psíquica da vítima - parece desconsiderar a realidade do mundo do trabalho.

Tal vertente domina parte da jurisprudência há anos: Sônia Mascaro Nascimento ${ }^{39}$, exemplificativamente, vai muito além do aqui exposto. Defende que a lesão à personalidade do indivíduo é requisito suficiente para a responsabilização civil do agressor por danos morais, mas não evidencia a prática de assédio moral. Este dependeria da prova técnica de ocorrência de dano psíquico. Embora o artigo da Professora Sônia Mascaro Nascimento tenha sido redigido há mais de dez anos, muitos julgados parecem seguir essa tendência ${ }^{40}$, eis que supostamente lastreada nas palavras da estudiosa tomada como referência no assunto, Marie-France Hirigoyen.

Em verdade, esta perseguição psicológica não pertence ao conceito de assédio moral; o abalo psíquico pertence à própria cultura e ao poder existentes nas organizaçóes empresariais, como bem observa Everaldo Gaspar Lopes de Andrade. Na verdade, esses traumas psicológicos, segundo o autor, já compóem o mundo do trabalho e "não importa que o trabalhador esteja ou não empregado. Os sobressaltos, decorrentes dessa insegurança,

38 ALKIMIN, Maria Aparecida. Assédio moral na relação de emprego. Curitiba: Juruá, 2005. p. 52.

39 NASCIMENTO, Sônia A. C. Mascaro. O assédio moral no ambiente do trabalho. Revista LTr, São Paulo, v. 68, n. 08, p. 925. ago./2004.

40 Veja-se a Ementa de recentíssimos Acórdãos de diferentes regiōes do Brasil. Um deles é oriundo do Tribunal Regional do Trabalho da 2a Regiāo (São Paulo): "ASSÉDIO MORAL NÃO COMPROVADO. INDENIZAÇÃO INDEVIDA. A figura do assédio moral se consubstancia na pressáo psicológica do empregador ou preposto, com caráter não eventual, na busca de fazer dos constrangimentos perpetrados no trabalho, instrumento de verdadeira coação, para obtenção de maior produtividade ou mesmo para ensejar a iniciativa do empregado em rescindir o seu contrato de trabalho. O trabalhador passa a ser vitima de um ambiente de insustentável instabilidade emocional. Logo, ao aplicador do direito cabe analisar as circunstâncias e particularidades do caso concreto, à luz dos princípios da razoabilidade e da proporcionalidade. Assim, havendo comprovação nos autos quanto ao tratamento humilhante dispensado ao empregado e a culpa do empregador, necessária a condenação ao pagamento de reparação por danos morais. Todavia, não restou comprovado nos autos qualquer tratamento inadequado dispensado ao demandante. Apelo do autor a que se nega provimento" (grifos nossos). Processo TRT 2a Região 00025052120135020262, Relator Desembargador Valdir Florindo. Publicado no DJe em 23 fev. 2015. É também assaz representador desta tese outro Acórdão de recente lavra, oriundo do Tribunal Regional do Trabalho da 6a Região (Pernambuco), no qual se destaca: "segundo os ensinamentos doutrinários, o assédio moral decorre de tortura psicológica, consubstanciada no terror de ordem pessoal, moral e psicológica, praticada contra o empregado, no âmbito da empresa, podendo ser exercitada pelo superior hierárquico, por grupo de empregados do mesmo nivel e pelos subordinados contra a chefia, visando a tornar insuportável o ambiente de trabalho, obrigando o trabalhador a tomar a iniciativa, por qualquer forma, do desfazimento do contrato de trabalho" (grifos nossos). Processo TRT 6a Regiāo 0000556-40.2013.5.06.0103, Relatora Desembargadora Eneida Melo Correia de Araújo. Publicado no DJe em 23 mar. 2015. 
dessa incerteza constituem o substrato, a essência desse modelo, que faz sentir física e metafisicamente imprestável”¹.

A assertiva lançada pelo autor retrocitado elucida bem o que se tenta expor: não apenas em relaçóes formais de emprego, mas também em outras - irregulares, clandestinas e até ilícitas, como citado - o terror psicológico é sistêmico e, por isso, deixa de conceituar o assédio moral, ao contrário do que se verifica facilmente em diversos julgados. As empresas, em sua maioria, trabalham com sistemas panópticos, fato que, de per si, cria ou potencializa qualquer clima de terror psicológico ${ }^{42}$. Caso se pretenda propor um conceito seguro de assédio moral, que venha a abarcar a real violência praticada contra subordinados no cotidiano das relaçóes laborais, há que se estudar sua estrutura conceitual.

\section{Em Busca de um Conceito de Assédio Moral: Proposições}

Em direito não se pode tomar a causa pelo seu efeito: o desrespeito à dignidade da pessoa humana que seja reiterado, sistemático, protraindo-se no tempo, poderá causar danos psíquicos ou mesmo físicos a uma pessoa. Quando se atenta diretamente contra a dignidade humana, pode-se ter efeitos vários: dano moral, dano psíquico, dano físico, dano estético, dano existencial ou, simplesmente, dano algum. Independentemente do

41 ANDRADE, Everaldo Gaspar Lopes de. O Direito do Trabalho na Filosofia e na Teoria Social Crítica: os sentidos do trabalho subordinado na cultura e no poder das organizaçóes. São Paulo: LTr, 2014. p. 125.

42 O Panóptico, idealizado por Bentham, foi uma espécie de sistema prisional muito bem explicitada por Michel Foucault: "o princípio é conhecido: na periferia uma construção em anel; no centro, uma torre; esta é vazada de largas janelas que se abrem sobre a face interna do anel; a construção periférica é dividida em celas, cada uma atravessando toda a espessura da construção; elas têm duas janelas, uma para o interior, correspondendo às janelas da torre; outra, que dá para o exterior, permite que a luz atravesse a cela de lado a lado. Basta então colocar um vigia na torre central, e em cada cela trancar um louco, um doente, um condenado, um operário ou um escolar. Pelo efeito da contraluz, pode-se perceber da torre, recortandose exatamente sobre a claridade, as pequenas silhuetas cativas nas celas da periferia. Tantas jaulas, tantos pequenos teatros, em que cada ator está sozinho, perfeitamente individualizado e constantemente visivel. $O$ dispositivo panóptico organiza unidades especiais que permitem ver sem parar e reconhecer imediatamente. Em suma, o princípio da masmorra é invertido; ou antes, de suas três funçóes - trancar, privar de luz e esconder - só se conserva a primeira e suprimem-se as outras duas. A plena luz e o olhar de um vigia captam melhor que a sombra, que finalmente protegia. A visibilidade é uma armadilha". in: FOUCAULT, Michel. Vigiar e Punir. Trad. Raquel Ramalhete. 29. ed. Petrópolis: Vozes, 2004. p. 165-166. Desta forma, não há mais necessidade de castigo para um eventual descuido do empregado, tampouco espaço para possíveis justificativas operárias de não adimplemento das tarefas. O temor da possibilidade de punição não apenas está instaurado permanentemente, mas dotado de uma certeza matemática. $\mathrm{O}$ medo substitui, por fim, a força, radicado apenas na lembrança desta. O poder simbólico do empregador e a violência do medo imposto estão introduzidos na relaçấo de emprego. E, desta maneira, o estado consciente e perene de vigilância garante o funcionamento automático do poder, independentemente de o empregador estar ou não efetivamente fiscalizando seus empregados. Finda-se o binômio ver, ser-visto, típico das pequenas empresas ou das antigas organizações empresariais. Tudo pode ser visto, controlado e vigiado como nos reality shows, tão comuns nesse começo de século XXI. 
dano que vier a configurar-se, o assédio moral poderá restar configurado, a depender de um somatório de fatores.

Ressalva-se desde já que quando o objeto do assédio não é o atentado à dignidade humana, e sim à própria integridade psíquica ou física da vítima, visando desestabilizá-la emocionalmente, aí sim ter-se-á assédio moral de vertente psicológica, que os espanhóis costumam denominar acoso psíquico. Este termo, segundo Francisco González Navarro, distingue-se absolutamente do termo "acosso moral": esta terminologia possui, em seu sentir, uma carência de precisão, pois se emprega o termo moral da mesma forma como o é empregado em situaçôes extrapatrimoniais, como a responsabilização por dano moral ${ }^{\not 3}$.

Francisco González Navarro diferencia corpo e alma, porque o corpo não é a pessoa; o corpo pertence à pessoa. Há, portanto, uma esfera interior (alma) e a exterior (corpo), sendo que a alma se torna explícita por meio do corpo, que a demonstra alegre, triste, cansada, etc ${ }^{44}$. A alma possui seus sentimentos, suas dores, que por sua vez se manifestam num corpo que também, de maneira exteriorizada, tem suas dores. A pessoa humana é, portanto, um sistema: corpo e alma, absolutamente interligados, sendo o corpo dirigido pela alma que ele, digamos, representa ${ }^{45}$. Por isso, Navarro sentencia que, pelas mais diferentes maneiras e objetivos possíveis, o agressor tem por objeto no acosso psíquico uma coisa apenas: a alma da vítima, a fim de poder domesticá-la, submetê-la ao seu domínio ${ }^{46}$. Nesse sentido, há assédio moral de cunho psicofísico o qual, todavia, não é regra.

Definição bastante precisa é a de Christophe Radé, quando afirma o assédio moral como comportamento hostil e violência moral reiteradamente travados contra a dignidade do empregado. Aliás, a Lei de 17 de janeiro de 2.002 declina o conceito de assédio moral como "agissements repetes (...) qui ont pour objet ou pour effet une dégradation des conditions de travail susceptible de porter atteinte à sés droits et à as dignité, d'altérer sa santé physique ou mentale ou de compromettre son avenir profissionnel' 47.

Nota-se, pelo conceito acima exposto, a clareza do legislador francês em distinguir danos físicos e psíquicos do conceito de assédio moral, o que pode ser reputado como correto. $\mathrm{O}$ assédio moral é uma prática reiterada que atenta contra direitos e contra a dignidade da pessoa humana. Esse é seu conceito. O dano, seja ele físico ou psíquico, é

43 GONZÁlEZ NAVARRO, Francisco. Acoso psíquico en el trabajo: el alma, bien jurídico a proteger. Madrid: Civitas, 2002. p. 173.

44 Id., p. 72-75.

45 Id., p. 83-96.

46 Id., 127-128.

47 RADÉ, Christophe. Harcèlement moral et responsabilités au sein de l'enterprise: l'obscur éclaircissement. Droit Social, Paris, p. 826. sept./oct. 2006. Tradução livre: "atitudes repetidas (...) que têm por objeto ou por efeito uma degradação das condições de trabalho, suscetível de poder atentar a seus direitos e à sua dignidade, de alterar sua saúde física ou psíquica, ou de comprometer seu futuro profissional". 
o efeito, a consequência da conduta assediante. Essa confusão parece permear não apenas a doutrina, como a jurisprudência brasileira também, tal qual já se buscou sublinhar no presente texto.

Alberto Pizzoferrato afirma que o assédio moral pode revestir-se tanto em forma coletiva quanto individual, expresso por uma multiplicidade de comportamentos agressivos não tipificados em princípio, mas com o requisito da repetitividade e continuidade, que podem redundar num ambiente de trabalho intolerável para a vítima ou as vítimas. No entanto, quanto aos efeitos causados pelo assédio moral, o autor sustenta que a prática não deve ser tida em razão da sensibilidade específica da vítima: deve-se ter em consideração a figura geral da pessoa mediana, pois somente assim ter-se-ia uma proteção maior a diversos tipos de situaçôes que poderiam enquadrar-se como assédio moral. Por fim, Pizoferrato vê, na tutela ressarcitória um caráter tanto reparatório e compensativo pelos danos sofridos, como um aspecto punitivo e preventivo no que tange à prática deste fenômeno pelo empregador ${ }^{48}$.

A motivação para a prática assediante pode ser tanto excludente quanto inclusiva, ou seja, como espécie de "incentivo" à produção mas que, pela forma como se apresenta, poderá ferir direitos fundamentais do trabalhador. Muitas vezes, é por meio do assédio moral que o empregador ou quem lhe faça as vezes procura "impulsionar" o empregado a produzir mais; em outras, é pelo terror psicológico, advindo da constante ameaça de perda do emprego, que o empregador obriga o subordinado ao cumprimento máximo dos trabalhos impostos, por mais penosos que sejam.

Essa motivação pode fazer parte da conduta, mas não a delimita; o terror psicológico e os possíveis danos causados à vítima são efeitos da conduta, e não a conduta per se. Não sendo possível prever quantas e quais serão as formas pelas quais o assédio moral poderá manifestar-se, este poderá ser conceituado sempre que se atentar contra a dignidade e a personalidade do empregado. Sua integridade física e psíquica encontra-se ameaçada - potencialmente ameaçada, ao menos, pois a prática de assédio moral teve como base a violação sistemática a direitos fundamentais.

De fato, a perseguição poderá ser considerada psicológica apenas se tida no sentido de que poderá, potencialmente, afetar a integridade psíquica da vítima, mas não supóe uma motivaçâo especificamente excludente para sua configuração. Neste sentido é que se configura algo que poderá ser denominado como violência instrumental: por meio dela, e mesmo sem dolo, o empregador poderá assediar seus empregados, numa clássica figura do ilícito civil chamada abuso do direito.

48 PIZZOFERRATO, Alberto. Mobbing e danno esistenziale: verso uma revisione della struttura dell'illecito civile. Contratto e impresa, Padova, v. 18, n. 1, p. 304-311. gen./apr. 2002. 
Na mesma esteira, acentua o autor lusitano Mago Graciano de Rocha Pacheco:

o assédio moral caracteriza-se por ser um tipo de violência que não é visível, que não transparece para o exterior e que dele não transparecem sequelas, excepto as resultantes de danos psicológicos, quando estas ocorrem e que, mesmo assim, podem sempre ser afastadas pelo assediador, atribuindo ao assediado problemas pessoais, perturbaçôes mentais de longa data ou de mau relacionamento com os demais companheiros de trabalho ou outros da mais diversa índole ${ }^{49}$.

Prossegue o autor em suas escorreitas consideraçóes, ponderando que o caráter sutil da violência perpetrada contra o empregado pode por ele sequer ser notado; são fragmentos cotidianos de desrespeito à integridade moral dos trabalhadores que os empregados vivenciam, dia após dia, e muitas vezes sequer notam a prática.

Assim, nas palavras exatas do já citado autor,

a caracterização dos diversos actos em que se traduz o assédio moral, como actos de violência psicológica, não deve ser acolhida pelo Direito. Trata-se de um requisito do assédio moral para os domínios da psicologia e da psiquiatria, contudo, não deve ser considerado como elemento do conceito jurídico de assédio moral, porque este fenómeno pode compreender actos de violência física, porque pode não comportar qualquer consequência psicológica e, também, porque esta expressão "violência psicológica" induz na exigência de um dano psíquico que, por seu turno, não pode ser tido como elemento integrante deste tipo de violência, uma vez que o assédio moral releva, tấo-só, pela ofensa à integridade moral do trabalhador enquanto pessoa humana ${ }^{50}$.

Por isto, o assédio moral poderá ser aquele em que o empregador, utilizando-se abusivamente do seu direito subjetivo de organizar, regulamentar, fiscalizar a produção e punir os empregados, vale-se dessas prerrogativas de forma reiterada e sistemática, como politica gerencial, atentando contra direitos fundamentais dos empregados em todas as suas dimensôes, geralmente para o incremento de sua produção. O poder diretivo do empregador é, se assim utilizado, a mola-mestra que impulsiona a produçáo, com base no sacrifício e no desrespeito aos direitos dos subordinados. Por ser prática reiterada, dirigida a uma pessoa, um grupo ou ao ambiente do trabalho como um todo e atentar contra direitos fundamentais dos trabalhadores, constitui assédio moral.

Note-se que a prática de assédio moral como acima narrado somente é possível pela utilização da violência instrumental, ou seja, a violência nem sempre percebida - ou tida

49 PACHECO, Mago Graciano de Rocha. O Assédio Moral no Trabalho: o elo mais fraco. Coimbra: Almedina, 2007. p. 74 .

50 Id., p. 77-78. 
como normal por parte dos empregados e da sociedade - para que a empresa logre as finalidades que deseja obter. Uma espécie totalitária de governança empresarial, certamente.

Georges Sorel já discutiu acerca da moralidade da violência para se obter determinados fins, e a mostra não como um dado novo, e menos ainda desconhecido. Segundo o autor, o próprio cristianismo jamais teria conseguido adotar a força que hoje tem, enquanto fé, se não se utilizasse, em seus primórdios, da violência para conseguir seus objetivos $^{51}$. Assim, a violência pode servir a qualquer grupo ou governo como instrumento para que alguém seja "incluído" em determinada esfera, numa prática que parece bastante totalitária.

Nesse aspecto, pode-se traçar dois paralelos com o pensamento de Hannah Arendt. Não que uma empresa possa ser totalitária, na acepção que o tempo possui na filosofia política, mas pode adotar táticas de inspiração nitidamente totalitárias para o aumento da produção. O totalitarismo é aquele sistema que destrói os valores, as tradiçóes, as políticas de seus comandados. Ao mesmo tempo, cria uma cultura absolutamente nova, única, e a impóe indistintamente a todo o corpo de subordinados: como num rolo compressor, o poder totalitário reprime até mesmo o mais vulgar e primeiro dos direitos, que é o direito à liberdade: liberdade de criar, de pensar, de inovar, de crer em algo. O sistema totalitário, como a própria nomenclatura sugere, é total: não permite nada que esteja além do seu sistema cultural imposto ${ }^{52}$. Trata-se, pois, da corrosão dos valores morais da pessoa humana.

Quando a empresa, por exemplo, não respeita a personalidade de seus empregados, tisna o ambiente do trabalho, cria e fomenta a disputa acirrada entre seus empregados, nega o direito à filiação sindical como exigência para permanência no emprego, enfim, ela nada mais faz senão impor, à moda totalitária, o seu modelo cultural, ético, que não abre espaço às diferenças e não tolera dissidências. Tem-se, nesse caso, nada mais que o assédio moral - e não se falou até agora em quais eventuais danos tal assédio poderá causar.

É impossível também não invocar os ensinamentos de Hannah Arendt para falar acerca da figura de Eichmann. O alemáo Adolf Eichmann foi um dos braços direitos de Hitler na execução de judeus durante a Segunda Guerra Mundial, e se responsabilizou pela identificação, transporte, logística, etc., de todos os seres humanos a serem exterminados, de acordo com as ordens por ele recebidas.

Eichmann, por ser tenente-coronel e responsável pelas execuçôes, por diversas vezes teve o mesmo papel de Pôncio Pilatos - decidir entre a vida e a morte. Mesmo assim, com o passar dos anos, ele deixou de sentir qualquer coisa. Nada o impediria de mandar

51 SOREL, Georges. Reflexóes sobre a Violência. São Paulo: Martins Fontes, 1992. p. 206-207.

52 ARENDT, Hannah. Origens do Totalitarismo. Trad. Roberto Raposo. Sáo Paulo: Companhia das Letras, 2007. p. 512. 
matar, simplesmente porque a ordem era matar e, mais que isso, ele estava agindo não só em acordo com esta ordem, mas em acordo com o sistema legal de seu país. Desta feita, Eichmann não teve, jamais, qualquer crise de consciência, mesmo sabendo - como é comum a qualquer pessoa saber - que tirar a vida de outro ser humano, sem nenhuma razão, só pode ser um ato criminoso. Mas na Alemanha de Hitler isso não era uma aberração; era a regra. Destarte, "o mal, no Terceiro Reich, perdera sua maior qualidade, pela qual a maioria o reconhece $-\mathrm{o}$ aspecto da tentação" ${ }^{33}$.

Esta é a forma pelo qual o mal é banalizado: quando ele se torna ordem, regra, norma passível de cumprimento diário: não se questiona o porquê de as coisas serem geridas como são, inclusive na cultura existente nas organizaçóes empresariais, como anteriormente dito. Se uma empresa violenta sistematicamente os direitos fundamentais de seus empregados em nome da produção, justificando-se no princípio constitucional da livre iniciativa (que é fundada na valorização do trabalho humano, e não em sua degradação), nada há que se questionar. Tudo pertence à ordem natural das coisas, da produção, posto que é o econômico que determina o direito, e não o contrário, nesse pensar.

No entanto essas práticas, que se podem denominar como atos de violência instrumental, feitos com o escopo de atingir os objetivos unilateralmente impostos pelo empregador, moldar a personalidade dos empregados e o ambiente do trabalho táo-só pela vontade ditada pelo empregador, impregnar toda a empresa apenas com os valores patronais - e não os valores, também, das pessoas que produzem para a organização, numa prática manifestamente abusiva do poder diretivo do empregador, violentando direitos fundamentais dos empregados em todas as suas dimensóes - a isto também se denomina assédio moral.

Para uma compreensão inicial do problema, cita-se Vincent de Gaulejac:

na empresa "performática", o stress não é considerado uma doença profissional, mas um dado quase natural ao qual convém se adaptar. É bastante difundido que a "resistência ao stress" é exigida como uma qualidade necessária para se ter sucesso. Em vez de interrogar suas causas, aprendese a "geri-lo". Esta gestão consiste em domesticá-lo através de exercícios ou dispositivos variados [...]. Nesse domínio, a imaginação dos experts é sem limites. Não se procura resolver o problema atacando suas causas. O stress é considerado um mal necessário ao qual convém se adaptar, canalizando-se seus efeitos mais nocivos ${ }^{54}$.

53 ARENDT, Hannah. Eichmann em Jerusalém: um relato sobre a banalidade do mal, Trad. Sonia Orieta Heinrich. São Paulo: Diagrama \& Texto, 1983. p. 162.

54 GAULEJAC, Vincent de. Do assédio moral ao assédio social. in: SEIXAS, Jacy; BRESCIANI, Maria Stella. Assédio moral: desafios políticos, consideraçóes sociais, incertezas jurídicas. Uberlândia: EDUFU, 2006. p. 76 
Esta visão de empresa é aquela que propicia práticas constantes de assédio moral, ainda que o assediador seja a própria estrutura da organização - melhor dizendo, sua cultura e modus operandi. A lesão reiterada à saúde psicofísica de um empregado, ou de um grupo de subordinados, assim como a lesão ao próprio ambiente de trabalho em si mesmo considerado, traduzem-se, também, em assédio moral.

Pertinente e relevante, neste contexto, o estudo de Carlos Eduardo Carrusca Vieira. $\mathrm{O}$ autor ora citado demonstra a relevância social do trabalho como um marco central na vida de qualquer pessoa. Os indivíduos traçam suas trajetórias e constroem suas identidades com base nos atributos qualificativos oriundos de seu ato de trabalhar ${ }^{55}$. A importância que o trabalho adquire para a pessoa dos trabalhadores pode assim ser sucintamente descrita:

principalmente em razão do fato de que a vida diferenciou suas inserçôes, em virtude do recuo da mono-atividade e dos progressos da contingência biográfica, que o trabalho se acha de tal maneira investido pelos sujeitos. Eles requerem muito mais dele do que antes. Em particular, que ele seja um meio de realização de todas as vidas que julgam merecer. Mas também um meio de invenção destas vidas. $\mathrm{O}$ trabalho está portanto menos no centro e, em termos paradoxais, mais no centro. Menos no centro porque a vida profissional faz dele a parte de um todo que o ultrapassa amplamente. Mais no centro porque ele deve oferecer agora a cada um o poder de fazer algo de sua própria vida, de ser sujeito de sua história ${ }^{56}$.

Ora, adquirindo o trabalho esta característica de centralidade na vida do homem, não é de se estranhar, como bem nota Carlos Eduardo Vieira Carrusca, que o assédio invada a moral do trabalhador para penetrar seu campo psicossocial. Conforme bem salienta o autor,

o fato de um caso de assédio ocorrer no âmbito do trabalho ganha pouco lugar nas análises que seguem o viés "psicologizante". O local de trabalho parece ser concebido simplesmente como um "contexto", sem particularidades importantes, no qual o assédio se desenvolve. Como uma contingência casual, não relacionada ao fenômeno. Pouco se diz acerca das razóes pelas quais ele se apresenta nesse espaço e a respeito das particularidades desse fenômeno nesse âmbito ${ }^{57}$.

$\mathrm{O}$ ambiente do trabalho está frequente e diretamente relacionado à forma como se manifesta o assédio moral. Não se trata de um dado isolado, mas de toda uma cultura que

55 VIEIRA, Carlos Eduardo Carrusca. Assédio: do moral ao psicossocial. Curitiba: Juruá, 2008. p. 140.

56 CLOT, Yves. A função psicológica do trabalho. Trad. Adail Sobral. Petrópolis: Vozes, 2006. p. 73.

57 Op. cit., p. 97. 
permeia os locais de trabalho e, a depender das práticas empresariais, poderá caracterizarse como assédio moral.

$\mathrm{Na}$ esteira de suas corretas ponderaçôes, Lis Andréa Pereira Soboll qualifica como assédio moral também a gestão por medo, "estruturada no mecanismo que tem a ameaça, implícita ou explícita, como estímulo principal para gerar adesão do trabalhador aos objetivos organizacionais" 58 . Neste sentido, a já citada violência instrumental - porque instrumento destinado à satisfação dos interesses do empregador - é o que caracteriza verdadeiramente o assédio moral. $\mathrm{O}$ desrespeito frequente, prolongado ao longo do tempo, destinado a todo o grupo de empregados com a intenção de neles incutir como necessária a adoção da ética empresarial como ética própria, ou a gestão baseada na ameaça de puniçôes, de demissão, ou humilhações constantes que ferem a dignidade humana é, sem dúvidas, a forma de manipulação patronal que se utiliza do medo e da angústia engendrados no empregado como forma de aumentar a produtividade ${ }^{59}$.

É nesse sentido que o assédio moral nem sempre tem como objetivo, apesar de a jurisprudência e doutrina contemporâneas prenderem-se a tal conceito, minar a integridade psicofísica da vítima. Muitas vezes a prática de assédio poderá restar difusa na própria cultura gerencial da empresa: quando se intensifica o ritmo produtivo à exaustão, por exemplo, e depois resultados são comparados num mesmo ambiente, a intenção do empregador pode ser a de deliberadamente promover uma espécie de "competição" no ambiente do trabalho para que se verifique quem é capaz de produzir mais. Embora tal prática não seja ilícita, num primeiro olhar, grande é o potencial de esta comparação não conseguir aquilatar, por exemplo, a qualidade da produção, a experiência ou inexperiência de empregados que poderiam ensinar ou aprender melhor o trabalho, dentre uma série infinita de possibilidades. O problema é a consequência: quantos empregados poderão sentir-se diminuídos na empresa, já que não conseguem trabalhar "bem", ao menos no conceito da empresa? Considerando a importância que o trabalho ocupa na vida de um ser humano - é central - um conceito equivocado de "competição" poderá engendrar muitas consequências.

Há um exemplo na obra de Carlos Eduardo Carrusca Vieira que parece demonstrar, com perfeição, a prática de assédio moral na forma comentada. $\mathrm{O}$ autor (que é Psicólogo) examinou o caso de Ricardo, vigilante de um banco afastado do trabalho em razão de Transtorno de Estresse Pós-Traumático. Cada vez mais Ricardo, o qual prestava serviços a

58 SOBOLL, Lis Andréa Pereira. Assédio Moral/Organizacional: uma análise da organização do trabalho. São Paulo: Casa do Psicólogo, 2008. p. 82.

59 EBERle, André Davi; SOBOLL, Lis Andrea Pereira; CREMASCO, Maria Virgínia Filomena. Compreensóes sobre o assédio moral no trabalho a partir da psicodinâmica do trabalho. in: GOSDAL, Thereza Cristina; SOBOLL, Lis Andrea Pereira (orgs.). Assédio Moral Interpessoal e Organizacional. Sáo Paulo: LTr, 2009. p. 112. 
um Banco de forma terceirizada, passou a ser visto como "chato" e "ridículo", sendo alvo de zombaria por parte dos empregados bancários por ater-se demasiadamente às normas de segurança de sua empresa.

Curiosamente, por ser zeloso guardador das regras prescritas de conduta de seu verdadeiro empregador, os colegas que frequentavam o mesmo ambiente de trabalho tomavam-no como o chiste do "cadê seu crachá?". Ricardo era desmoralizado, pelos colegas, perante clientes do Banco, vendedores de queijo, de revistas, de perfumes e cosméticos, enfim, pessoas as mais diversas que, embora não pertencentes ao quadro de empregados da empresa, perambulavam pelo ambiente do trabalho com assiduidade, lá desenvolvendo e estabelecendo relaçôes. Nestas relações, passaram a valorar a figura de Ricardo negativamente, chegando até mesmo um dos bancários a ameaçar agredi-lo "lá na rua" 60 . Como não relacionar esse assédio moral com o ambiente do trabalho da vítima? Não se tratou, à evidência, de perseguição psicológica do empregador e, mesmo sendo trabalho terceirizado, inexistiu prática atentatória à integridade psíquica do trabalhador por parte do Banco, que era o tomador de serviços.

Desta forma, não se pode tomar a causa pelo seu efeito: o desrespeito à dignidade da pessoa humana que seja reiterado, sistemático, protraindo-se no tempo, poderá causar danos psíquicos ou mesmo físicos a uma pessoa. Quando se atenta diretamente contra a dignidade humana, pode-se ter efeitos vários: dano moral, dano psíquico, dano físico, dano existencial ou, simplesmente, dano algum. De qualquer forma, ainda que sem danos, o assédio moral restará configurado.

A discussão em torno do conceito de assédio moral começa a ganhar relevo quando, em se verificando um dano - moral, psíquico, à saúde, estético ou existencial - se conduz à conclusão médica de que a doença profissional (ou relacionada ao trabalho) é derivada de um fenômeno, que pode ser definido como constrangimento organizado. Isso situa, de maneira irrefutável, o assédio moral não mais no âmbito da perseguiçâo psicológica, mas como uma responsabilidade corporativa e organizacional da empresa ${ }^{61}$, organização esta patrocinada, conforme visto, pelo poder diretivo do empregador.

Consoante acima afirmado, o assédio moral existe por si só, independentemente dos danos que venha a causar. Responsabilizar civilmente quem pratica assédio moral, seja de qual forma ele se apresentar, é uma forma não apenas de punir quem cometa ilícitos, mas também de prevenir possíveis danos. Esta dupla função - punitiva e preventiva - conferida à responsabilização de quem pratique assédio moral, retirando de seu conceito qualquer viés "psicologizante", qual se defendeu nestas letras, é uma forma pela qual o Judiciário

60 VIEIRA, Carlos Eduardo Carrusca. Assédio: do moral ao psicossocial. Curitiba: Juruá, 2008. p. 90.

61 GULOTTA, Guglielmo. Il vero e il falso mobbing. Milano: Giuffrè, 2007. p. 13. 
poderá inibir um sem-número de casos de violência observados em relaçóes de trabalho. Giselda Maria Novaes Hironaka desenvolve interessante trabalho acerca da responsabilidade civil que prescinda até mesmo do elemento culpa, que foi (e ainda é) muito caro à dogmática do direito civil: é preciso que o sistema de reparação civil, mormente por danos de natureza moral, tenha mais a noçáo de proteçáo aos direitos fundamentais do que, necessariamente, o ressarcimento ou a punição. Conforme a autora,

certamente têm razão os juristas da contemporaneidade que reclamam por uma construção legislativa que garantisse mesmo, não caso a caso, mas sob uma formatação mais genérica, essa hipótese de imputação legal de responsabilidade não individualizada, quer dizer, coletivizada, tendo em vista que tal providência retiraria a variação jurisprudencial que ainda existe e que pode conter, pelos seus traços de imutabilidade, resquícios de injustiça e ausência de eqüidade. Atualmente, a atenção de todo o sistema de responsabilidade civil se volta, assim como se disse, para as vítimas, não apenas porque os danos são mais graves, mas também, e sobretudo, porque em quase todos os casos o responsável tinha a possibilidade ou a obrigação de se garantir e garantir a segurança dos demais, aos quais acaba por vitimar ${ }^{62}$.

Embora a autora critique em termos a noção de "exposiçáo ao risco" como cláusula geral para aferiçáo da responsabilidade civil independentemente de culpa, pelo só fato de ser o conceito muito amplo e vago, crê-se que esta soluçấo seria eficiente em se tratando da absoluta maioria das relaçôes laborais havidas num ambiente do trabalho ${ }^{63}$. Logicamente, esta fórmula de cláusula geral não retiraria outras específicas acerca do tema da responsabilidade objetiva, afinal, mais do que nunca se faz necessário ampliar significativamente "as fronteiras de conformação deste risco, para não entendê-lo apenas como um risco material ou técnico, mas senáo, ainda, como um risco pelo fato da organização e mesmo como um risco pelo fato de outrem" ${ }^{\prime 4}$.

No caso, pode-se notar que o risco deve-se à própria cultura existente na organização empresarial: como é o empregador que a engendra por inteiro, utilizando-se do feixe de múltiplos poderes contidos em suas diretivas empresariais, deverá ele responder objetivamente pela violaçáo sistemática de direitos, prática essa que, do início ao final, está a propiciar ainda que potencialmente um dano de natureza qualquer. Isto porque o assédio moral é ato ilícito per se, sendo qualquer dano oriundo de sua prática objeto de tutela própria.

62 HIRONAKA, Giselda Maria Fernandes Novaes. Responsabilidade Pressuposta. Belo Horizonte: Del Rey, 2005. p. 144.

63 Id., p. 281-342.

64 Id., p. 340-341. 


\section{Conclusões}

Observou-se ao longo deste trabalho a modificação paulatina do conceito de assédio moral, tanto na literatura jurídica quanto na experiência, brasileira e estrangeira, relacionadas à conceituação do problema. Se inicialmente tido mais por seus efeitos do que por seu conceito mesmo, o assédio moral cada vez mais passa a ser enxergado como a lesão reiterada aos direitos fundamentais dos trabalhadores, e não, necessariamente, como a perseguição psicológica deliberadamente deflagrada contra um ou alguns indivíduos, embora os Tribunais ainda reconheçam nessa perseguição um requisito para configurar-se a prática de assédio moral.

A prática de assédio moral guarda autonomia em relação aos danos que poderá causar, sejam eles de natureza material, moral, estética, existencial ou psíquica. Quando o empregador - ou quem lhe faz as vezes (em regra superiores hierárquicos de alta envergadura na estrutura empresarial) - pratica atos que atingem um indivíduo, um grupo ou mesmo a coletividade da empresa e traz a violaçáo a direitos fundamentais como cultura organizacional, certamente o dador de ordens estará a cometer ato ilícito, nas letras do artigo 187 do Código Civil. Ainda que deste ato não haja qualquer dano, mormente psíquico, para os subordinados em geral, a simples violaçâo a direitos fundamentais travada de forma reiterada já constitui fenômeno digno de tutela, pela qual o empregador deverá ser punido com indenizaçáo pecuniária, a teor do artigo 927 do Código Civil. Esta indenização, que poderá voltar-se em benefício de um ou mais trabalhadores, ou fundo de natureza social, constitui forma eficiente de punir aquele que pratica assédio moral, além de prevenir, no âmbito da cultura e do poder existentes nas organizaçôes, a sua prática.

Não há como considerar que a prática de assédio moral esteja intrinsecamente ligada a alguma perseguição psicológica deliberadamente travada contra alguém, a não ser em casos específicos. Quando vier a ocorrer tal fenômeno, por certo a tutela indenizatória à vítima será ainda maior, tendo em vista a extensấo do dano provocado pela prática assediadora.

A figura de Eichmann, bem exposta por Hannah Arendt, confere a real dimensão destas consideraçôes finais. A produção em larga escala, a necessidade contínua e inexaurível dos trabalhadores em geral em procurar por emprego, a dificuldade em encontrá-lo, a ética difundida nos meios empresariais de "dar o sangue pela empresa" e o "mass media" permitiram acreditar que qualquer meio para alcançar a produção e o sucesso da empresa são válidos.

Num primeiro momento, os empregados passam a acreditar que o sucesso da empresa depende do desempenho individual deles e, mais ainda, que o sucesso da empresa é seu próprio sucesso individual. No abismo da indistinçấo que os empregadores provocam, em colocar seus interesses como interesses dos próprios empregados, também aqueles que 
permanecem do outro lado dos muros da empresa são um pouco Eichmann: acreditam na banalidade do mal, na legitimidade do empregador em cobrar as metas impostas aos seus empregados, na vigilância ostensiva que mantém sobre eles e, mais ainda: acreditam que é normal e, mais que isso, aceitável admitir o desrespeito sistemático a direitos fundamentais dos trabalhadores em nome da produção.

A explicação reside num argumento de relativa facilidade: tal prática não é vedada, explicitamente, pelo direito. $\mathrm{O}$ empregador possui o poder, conforme visto, tanto de organizar o ambiente do trabalho ao seu talante, como de regulamentá-lo, fiscalizá-lo e, mais ainda, punir o empregado que não se ativer às normas emanadas da autoridade patronal. Quando há relaçóes subordinadas irregulares, clandestinas ou ilícitas a situação chega a ser pior, pois nem mesmo direitos sociais são conferidos a tais trabalhadores. $\mathrm{E}$ não raro tais práticas não são fenômenos esparsos ou isolados: são políticas gerenciais, ou seja, atos reiterados de desrespeito e afronta aos direitos dos trabalhadores - no caso, políticas gerenciais que utilizam o assédio moral como o instrumento violento apto a obrigar os trabalhadores a produzir para além de suas forças físicas ou psíquicas.

Nesse diapasão o ora proposto conceito de assédio moral poderá servir para a resolução, ao menos em parte, desses problemas vivenciados no interior das empresas - ou, em termos de educação social em direitos humanos, na paulatina destruição do Eichmann que existe em cada ser humano. Pela demonstração do reiterado desrespeito aos direitos fundamentais dos trabalhadores, evidencia-se que a prática das empresas em pedir o máximo de seus empregados pela produção deve coexistir com a garantia de um ambiente do trabalho que respeite a pessoa humana em sua integralidade e na múltipla extensão de seus legítimos valores morais.

Havendo produção, mas sendo esta alcançada pelo desrespeito aos valores humanos dos empregados, por razóes como cultura gerencial, afirma-se que se estará diante do conceito jurídico de assédio moral, que possui tutela própria e independente, para além de aplicar-se a empregados individualmente considerados ou a toda uma organização. Com a observação desses aspectos de cimeira importância, propóe-se contribuir para uma tutela mais eficiente dos direitos fundamentais dos trabalhadores em seus ambientes do trabalho, estejam tais pessoas em relaçóes formais ou informais de emprego.

\section{Referências}

ALKIMIN, Maria Aparecida. Assédio moral na relaçáo de emprego. Curitiba: Juruá, 2005.

ANDRADE, Everaldo Gaspar Lopes de. Direito do Trabalho e Pós-Modernidade: fundamentos para uma teoria geral. São Paulo: LTr, 2005. 
O Direito do Trabalho na Filosofia e na Teoria Social Crítica: os sentidos do trabalho subordinado na cultura e no poder das organizaçóes. São Paulo: LTr, 2014.

ARENDT, Hannah. Eichmann em Jerusalém: um relato sobre a banalidade do mal, Trad. Sonia Orieta Heinrich. São Paulo: Diagrama \& Texto, 1983.

. Origens do Totalitarismo. Trad. Roberto Raposo. São Paulo: Companhia das Letras, 2007.

BARASSI, Lodovico. Il diritto del lavoro: le fonti, il rapporto di lavoro, le qualifiche. v. 1. Milano: Giuffrè, 1949.

BENDIX, Reinhard. Trabajo y autoridad en la industria: las ideologías de la dirección en el curso de la industrialización. Trad. Ítalo A. Manzi e Ricardo Malfé. Buenos Aires: Editorial Universitaria de Buenos Aires, 1966.

BOURDIEU, Pierre. O Poder Simbólico. Trad. Fernando Tomaz. 8.ed. Rio de Janeiro: Bertrand Brasil, 2005.

CAMERLYNK, G. H. Traité de droit du travail: contrat de travail. Paris: Dalloz, 1968.

CASTEL, Robert. As metamorfoses da questáo social: uma crônica do salário. Trad. Iraci D. Poleti. 6. ed. Petrópolis: Vozes, 1998.

CLOT, Yves. A função psicológica do trabalho. Trad. Adail Sobral. Petrópolis: Vozes, 2006.

DELGADO, Maurício Godinho. Curso de Direito do Trabalho 13. ed. São Paulo: LTr, 2014.

EBERLE, André Davi; SOBOLL, Lis Andrea Pereira; CREMASCO, Maria Virgínia Filomena. Compreensôes sobre o assédio moral no trabalho a partir da psicodinâmica do trabalho. in: GOSDAL, Thereza Cristina; SOBOLL, Lis Andrea Pereira (orgs.). Assédio Moral Interpessoal e Organizacional. São Paulo: LTr, 2009. p. 105-138.

ENGELS, Friedrich. Sobre a autoridade. in: MARX, Karl; ENGELS, Friedrich. Obras Escolhidas. v. 2. São Paulo: Alfa-Ômega, s/d. p. 183-187.

EWALD, François. L'Etat Providence. Paris: Bernard Grasset, 1986.

FERRARI, Irany; NASCIMENTO, Amauri Mascaro; MARTINS FILHO, Ives Gandra da Silva. História do trabalho, do Direito do Trabalho e da Justiça do Trabalho. São Paulo: LTr, 1998.

FOUCAUlT, Michel. Microfísica do Poder. Trad. Roberto Machado. 21. ed. Rio de Janeiro: Graal, 2005.

. Vigiar e Punir. Trad. Raquel Ramalhete. 29. ed. Petrópolis: Vozes, 2004. 
GAULEJAC, Vincent de. Do assédio moral ao assédio social. in: SEIXAS, Jacy; BRESCIANI, Maria Stella. Assédio moral: desafios políticos, considerações sociais, incertezas jurídicas. Uberlândia: EDUFU, 2006. p. 71-82.

GONZÁLEZ NAVARRO, Francisco. Acoso psíquico en el trabajo: el alma, bien jurídico a proteger. Madrid: Civitas, 2002.

GULOTTA, Guglielmo. Il vero e il falso mobbing. Milano: Giuffrè, 2007.

HIRIGOYEN, Marie-France. Mal-estar no trabalho: redefinindo o Assédio Moral. Trad. Rejane Janowitzer. 2.ed. Rio de Janeiro: Bertrand Brasil, 2005.

HIRONAKA, Giselda Maria Fernandes Novaes. Responsabilidade Pressuposta. Belo Horizonte: Del Rey, 2005.

LEBRUN, Gérard. O que é poder. 14. ed. São Paulo: Brasiliense, 1996.

MAGANO, Octavio Bueno. Do Poder Diretivo na Empresa. São Paulo: Saraiva, 1982.

MELHADO, Reginaldo. Poder e Sujeição: os fundamentos da relação de poder entre capital e trabalho e o conceito de subordinação. São Paulo: LTr, 2003.

MESQUITA, Luiz José de. Direito disciplinar do trabalho. São Paulo: Saraiva, 1950.

MONTOYA MELGAR, Alfredo. El poder de dirección del empresário. Madrid: Instituto de Estudios Políticos, 1965.

MORAES FILHO, Evaristo de. Introduçáo ao direito do trabalho. v. 1. Rio de Janeiro: Forense, 1956.

NASCIMENTO, Sônia A. C. Mascaro. O assédio moral no ambiente do trabalho. Revista LTr, São Paulo, v. 68, n. 08, p. 922-930. ago./2004.

PACHECO, Mago Graciano de Rocha. O Assédio Moral no Trabalho: o elo mais fraco. Coimbra: Almedina, 2007.

PIZZOFERRATO, Alberto. Mobbing e danno esistenziale: verso uma revisione della struttura dell'illecito civile. Contratto e impresa, Padova, v. 18, n. 1, p. 304-321. gen./apr. 2002.

RADÉ, Christophe. Harcèlement moral et responsabilités au sein de l'enterprise: l'obscur éclaircissement. Droit Social, Paris, n. 9/10, p. 826-833. sept./oct. 2006.

ROMAGNOLI, Umberto. La libertad sindical, hoy. Revista de Derecho Social, v.4, n. 14, abr./jun. 2001. p. 9-23.

RUSSELL, Bertrand. O poder: uma nova análise social. Trad. Brenno Silveira. São Paulo: Companhia Editora Nacional, 1957.

RUSSOMANO, Mozart Victor. Curso de Direito do Trabalho. Rio de Janeiro: José Konfino, 1972. 
SCOGNAMIGLIO, Renato. Diritto del Lavoro. 2. ed. Bari: Cacucci, 1984.

SOBOLL, Lis Andréa Pereira. Assédio Moral/Organizacional: uma análise da organização do trabalho. São Paulo: Casa do Psicólogo, 2008.

SOREL, Georges. Reflexóes sobre a Violência. São Paulo: Martins Fontes, 1992.

SOUTO MAIOR, Jorge Luiz; GNATA, Noa Piatã Bassfeld (orgs.). Trabalhos marginais. São Paulo: LTr, 2013.

VIEIRA, Carlos Eduardo Carrusca. Assédio: do moral ao psicossocial. Curitiba: Juruá, 2008. 